REVIEW ARTICLE

\title{
INTERNATIONAL HUMANITARIAN LAW PROTECTION OF MEDICAL FACILITIES AND MEDICAL PERSONNEL IN THE ARMED FORCES OF THE CZECH REPUBLIC
}

\author{
Pavla Rozankova \\ International Law Department, Defence Policy and Strategy Division, Ministry of Defence, Prague, Czech Republic
}

Received $31^{\text {st }}$ August 2017.

Revised $1^{\text {st }}$ October 2017.

Published $8^{\text {th }}$ December 2017.

\begin{abstract}
Summary
Together with the protection of the sick and wounded in armed conflicts, rules of international humanitarian law (IHL) provide protection to medical facilities and personnel. Despite universal acknowledgement of these rules, their violations occur regularly. Causes of these violations are numerous and complex, however, in order to be respected, IHL rules need to be in the first place implemented within domestic legislations of individual states. Specific measures to be taken are to a certain extent left up to discretion of every state concerned. This article examines existing legislation and measures adopted in this context by the national authorities of the Czech Republic with respect to the Czech Armed Forces. A particular attention is directed at internal regulations of the Armed Forces against the wider background of Czech legal order. The article also touches upon areas of military training and criminal liability.
\end{abstract}

Key words: International humanitarian law; Geneva Conventions; protection of medical facilities and personnel; national measures; Armed Forces of the Czech Republic.

\section{Introduction}

During an armed conflict, medical facilities and personnel are, along with the sick and wounded, protected by norms of international humanitarian law (IHL). Currently, IHL norms concerning the protection of medical facilities and personnel can be found, in the first place, in the 1949 Geneva Conventions [1] and in the 1977 Additional Protocols to the Geneva Conventions [2] (hereinafter the "IHL Treaties"), while many of their rules are recognized as customary international law.

Despite the universal acknowledgment of norms protecting them, medical facilities and personnel in armed conflicts have, over the past years, faced an increased number of attacks and threats against them all over the world. This phenomenon poses enormous challenges to the humanitarian response and disrupts health-care services in those areas where they are most needed. This fact has not gone unnoticed by the international community and gave birth to several campaigns addressing this situation, e.g. Health Care in Danger (HCiD) by the International Red Cross and the Red Crescent Movement among the most engaged.

$\triangle$ Ministry of Defence, Defence, Policy and Strategy Division, International Law Department, Prague, Czech Republic 
HCiD focuses on a wide range of areas relevant to the protection of medical facilities and personnel (together with their patients) and identifies measures that might prevent such violence and ensure safe access to health care services in armed conflicts. These areas include, for example, domestic legislation or operational practices of the armed forces.

The aim of this article is to provide an example of a national approach. With this in mind, it offers a brief overview of the existing legislation and measures adopted by the national authorities of the Czech Republic with respect to the Czech Armed Forces with the view of implementing IHL rules on the protection of medical facilities and medical personnel in armed conflicts and ensuring that these rules are respected by the relevant stakeholders. The framework to be complied with by the Armed Forces of the Czech Republic is set out primarily by the Government represented by the Ministry of Defence. However, it cannot be perceived in isolation and needs to be set against the wider background of national law.

This article is based on a presentation made at the HCiD Conference: A Central and Eastern European Perspective held in Olomouc, Czech Republic, from 11-12 May, 2017, and hosted by Palacky University. This paper was written in a personal capacity and does not necessarily represent the views of the Ministry of Defence of the Czech Republic.

\section{Compliance and Dissemination}

Where it comes to obligations aimed at achieving compliance with IHL, Common Article 1 to the Geneva Conventions includes a general obligation of the contracting parties to respect and to ensure respect for the Conventions in all circumstances. This obligation is complemented by (and partly overlaps with) the so-called obligation to disseminate which requires the contracting parties, inter alia, to spread the knowledge of texts of the treaties as widely as possible and to include the study thereof in programmes of military instruction so that they are known to the armed forces and to the population as a whole.

Making the law known is just the very first step in ensuring compliance with the IHL Treaties. In relation to the Armed Forces, it has to be complemented by other measures involving the incorporation of IHL into the laws and regulations applicable to the military as well as their integration into military training and education with the overall goal of making them part of the military reality. These measures have to be accompanied by an appropriate system of sanctions and by effective law enforcement.

\section{National Laws and Regulations of the Czech Republic}

The Czech Republic is a contracting party to all of the IHL Treaties. Their position in the legal order of the Czech Republic is determined in Article 10 of the Constitution of the Czech Republic [3]. As such, they form part of the Czech legal order and they are directly applicable. Therefore, in the event of a conflict between a statutory provision and a provision of any of the IHL Treaties, the latter takes precedence. For this purpose, the IHL Treaties had to be promulgated in the Collection of Laws and International Treaties of the Czech Republic [4] together with their translation into the Czech language.

Direct applicability of the treaties enables their use in practice without the detailed incorporation of all of the relevant rules into national legislation. However, it is quite usual for certain obligations under the treaties to require further implementation in the form of specific laws adopted by the Parliament. In connection with the IHL Treaties, this applies, for example, to the obligation of a State to ensure prevention and repression of abuses of the distinctive emblem of the Red Cross [5]. To this end, the Act on the Protection of the Red Cross Emblem and Name and on the Czechoslovak Red Cross [6] was adopted by the Czech Parliament in 1992. The Act specifies which entities and individuals are authorized to use the emblem in the territory of the Czech Republic in peacetime and establishes sanctions for abuses of the emblem not amounting to criminal offences. Penal sanctions for abuses of the emblem are, together with sanctions for other serious violations of IHL, included in the Penal Code [7] (see below, Law Enforcement and Sanctions) which, therefore, represents another example of national legislative implementation of the IHL Treaties. 
Specifically in relation to the Armed Forces, the only statutory reference to compliance with IHL can be found in Section 48(1)(f) of the Act on Career Soldiers [8] in the form of a simply defined obligation of every soldier to comply with "international law of war and humanitarian law" [9].

More references to IHL rules intended to influence the military routine are contained in internal regulations applicable to the Armed Forces. A generally formulated obligation to comply with IHL is incorporated in the Basic Code of the Armed Forces of the Czech Republic [10], Article 35(f): "A soldier shall, in particular, follow the principles of law of war and international humanitarian law". In Article 37, the Basic Code also introduces the first rule which specifically concerns the protection of medical services, stating that "...medical facilities and their personnel, devices and equipment marked with an internationally recognized emblem... shall be untouchable". Article 38 addresses sanctions for abuse of internationally recognized emblems.

These references being undoubtedly too brief, more detailed provisions concerning the protection of medical facilities and personnel are contained in the Code of Conduct for Ground Operations of the Land Forces of the Armed Forces of the Czech Republic [11].

Rule 166 of the Ground Operations Code of Conduct incorporates fundamental obligations resulting from Geneva Convention I while using language which is very similar to Article 19 of the Convention: "Permanent medical facilities and mobile medical units shall not be attacked under any circumstances. They shall always be respected and protected by the Parties to the conflict. Should they fall into the hands of the adverse Party, they shall pursue their duties as long as the capturing Power has not itself ensured the necessary care of the wounded and sick found in such establishments and units".

Within the meaning of Article 19 of Geneva Convention I, rule 166 also sets out the requirements for the location of military medical facilities and units in military operations: they should be situated "in sheltered places outside the intense combat zone and marked with the Red Cross emblem visible during the day and at night". In this context, it is useful to mention that in 2015, the Czech Republic implemented [12] NATO Standardization Agreement on Distinctive Markings and Camouflage of Medical Facilities (STANAG 2931) which provides for an exception from the duty to use the emblem. Under certain strictly defined conditions, an authorized commander may determine the camouflage of medical facilities. While this option is in compliance with IHL rules [13] and it may be perfectly understandable in some situations in current armed conflicts, it will always be vital to carefully consider the operational needs as well as the consequences of such a decision for protection of medical facilities and their personnel [14].

Furthermore, rule 166 addresses also the loss of protection of medical facilities in case of their use for acts harmful to the enemy. This provision might include more details, in the least mentioning necessity of giving a due warning under Article 21 of Geneva Convention I.

Rule 167 addresses the protection of medical personnel by a general reference to the Geneva Conventions and Additional Protocols. In particular, it obliges them to wear the distinctive emblems and to carry special identity cards. The same rule regulates the status and treatment of captured military medical personnel in accordance with Articles 28 and 30 of Geneva Convention I.

Finally, rule 189 forbids the misuse of distinctive emblems and signals.

A simplified IHL manual which includes the most frequently used IHL terms and principles not included in the main body of the Ground Operations Code of Conduct is attached to the Code as Annex 1. It expressly mentions the categories of protected persons and recalls that the military medical service shall always be allowed to fulfil its tasks. Similarly, it emphasizes the obligation to permit the normal functioning of the civilian medical service.

\section{Education and Training}

Although the time allowed for IHL within military training is far from unlimited, it has become firmly anchored in the programmes of military instruction of the Czech Armed Forces after 1990. At present, IHL training, in which 
the protection of medical facilities and personnel in armed conflicts forms a fundamental part, is included in the programmes of military instruction on all levels right from the start of any soldier's career. The higher the rank, the more thorough the training: "It may be sufficient to teach recruits and members of the rank and file members the guiding principles - namely, protection of the wounded and of medical units and personnel, and respect for the distinctive emblem. On the other hand, Commanding Officers must have a very thorough knowledge of the Convention [15].” In addition, IHL instruction is intensified during pre-deployment training of military units.

Additional IHL courses are organized directly by the Ministry of Defence - for example a comprehensive IHL course that is held twice a year in close cooperation with the Czech Red Cross and attended by members of the Armed Forces together with Czech Red Cross IHL instructors.

The development of IHL training within the Czech Armed Forces received a further boost as a result of Czech NATO membership and participation in NATO multinational operations. In order to ensure that all military personnel deployed in NATO operations are properly trained and familiar with the IHL, the NATO Standardization Agreement on Training in the Law of Armed Conflict (STANAG 2449) was adopted. Its revised 2013 version (second edition; the first edition was promulgated in 2004 and adopted by the Czech Republic in 2007) establishes "a minimum standard of training" to ensure that NATO operations are conducted in accordance with IHL. It also provided the member states with a "Training Module Template" in the form of a PowerPoint presentation. It is a useful tool (not only) for national IHL instructors. It covers the main IHL rules, including the protection of medical units, transports and personnel as well as the protection of the distinctive emblem. The Czech Republic incorporated rules of the STANAG 2449 (second edition), in its training standards in 2016 [16].

What should be noted in the context of training is the role of military commanders, who are required to ensure that members of armed forces under their command are aware of their obligations under the IHL Treaties [17]. On national level this obligation results from duties of a superior set out in Article 49 of the Act on Career Soldiers. For this purpose and in accordance with Article 82 of the Additional Protocol I, the Ministry of Defence ensures that military commanders have legal advisers trained in IHL at their disposal [18].

\section{Law Enforcement and Sanctions}

An effective system for fixing individual criminal responsibility for crimes against the wounded and the sick, medical personnel, medical units and medical transports is one of the most frequently emphasized measures to be taken on the national level [19].

Therefore, apart from disciplinary sanctions [20] which can be imposed by the commanding officer for breaches of the above regulations, serious violations of IHL rules are subject to criminal liability. In contrast to disciplinary affairs, the Penal Code and jurisdiction of Czech civilian courts apply to military personnel of the Czech Republic to the same extent as they do to any other person who is subject to the national law of the Czech Republic.

Penalties for IHL violations are set out in the Penal Code [21], Chapter XIII, Crimes against Humanity, Peace and War Crimes. Protection of medical personnel and facilities is not expressed explicitly; however, it can be easily deduced from the definitions of individual offences. The relevant offences are as follows:

Use of Forbidden Means and Methods of Warfare:

- Penalizes the waging of combat in a forbidden way. This wording enables its application to a large scope of IHL violations; for example, it would be applicable to attacks against hospitals as well as medical personnel (Section 411(1)(b): "Whoever, in the situation of a war or an armed conflict or in a combat situation, gives an order to wage combat in a forbidden way or wages combat in such a way himself/herself shall be sentenced to imprisonment for two to ten years.").

- Penalizes intentional destruction of or damage to an object designated for humanitarian purposes. It would apply to attacks against hospitals and other medical facilities (mobile medical units or medical transports) 
as well as to objects of civil defence (Section 411(2)(d): "The same sentence (for two to ten years) shall be imposed to anyone who, contrary to the provisions of international law on the means and methods of waging a war or another armed conflict, intentionally destroys or damages an object designated for humanitarian purposes or abuses such object for military purposes.").

War Cruelty:

- Penalizes actions preventing or inhibiting civil defence organizations (the term of "civil defence" based on Articles 61 to 67 of Additional Protocol I is further implemented in Act No. 240/2000 Coll., on the Integrated Rescue System, as amended) from the performance of their humanitarian tasks (Section 412(2)(b): "The same sentence of imprisonment (for five to twelve years) shall be imposed on a person who, in the situation of a war or an armed conflict, intentionally violates international law regulations by preventing or inhibiting organizations of civil defence of the enemy or of a neutral or another state from the performance of their humanitarian tasks").

Abuse of International and National Recognised Symbols

- Penalizes the abuse of distinctive emblems in armed conflicts (Section 415(1): "Whoever, in the state of emergency, situation of a war or an armed conflict, abuses the Red Cross emblem or other distinctive emblems or colours recognized by international law for marking of medical facilities or medical transports or evacuation shall be sentenced to imprisonment for two to ten years").

Concurrent liability of a commander is formulated under Section 418 of the Penal Code and it is applicable to all criminal offences above. Respective commander is responsible for war crimes committed by subordinates over whom he/she exercised authority and control provided that he/she did not, even out of negligence, prevent them from the commission of such a war crime, punish them for it or hand them over to the authority competent for imposing such a punishment.

So far, no criminal proceedings for a war crime have been brought against any member of the Armed Forces of the Czech Republic, which means that none of these provisions had to be applied in practice.

\section{Conclusion}

Despite universal acknowledgement of IHL rules, their violations occur regularly and the area of medical services and personnel is just one of those significantly affected. Experts sometimes speak about "the widening gap between IHL and the reality in armed conflicts [22]" and together with the rest of the international community they search for new ways to strengthen compliance with IHL [23]. While the integration of IHL rules in national legislation together with dissemination and training measures do not represent an exhaustive list of measures necessary to be taken in order to ensure compliance, they undoubtedly remain its cornerstones.

The object of this article was to outline the protection of medical facilities and personnel in armed conflicts from the perspective of national laws and regulations of the Czech Republic. It needs to be acknowledged that a large portion of Czech legal norms implementing the IHL Treaties was adopted many years ago and some of these provisions might gain further precision and clarity if they were to be subjected to a review and possible revision. However, this concerns just a few rather minor issues. Apart from that it can be concluded that the relevant IHL rules have been implemented in a satisfactory manner on the statutory level as well as on the level of internal regulations of the Czech Armed Forces, both providing a good basis for the application of the rules in practice.

As for practical application, special focus needs to be given to military training as it has a real effect on strengthening the existing law. IHL training in the Czech Armed Forces has made significant progress and both the theoretical and the practical aspects are firmly established. However, its effectiveness should be evaluated on an ongoing basis. This is because it is respect for IHL rules by individual members of the armed forces together with an emphasis on the duties of commanders and a well-functioning and efficient chain of command what transforms written rules into reality. 


\section{Conflict of Interest Statement}

None declared.

\section{References and notes}

1. 1. Geneva Convention (I) for the Amelioration of the Condition of the Wounded and Sick in Armed Forces in the Field (opened for signature 12 Aug 1949, 75 UNTS 31, entered into force 21 Oct 1950) ('Geneva Convention I, GC I'); Geneva Convention (II) for the Amelioration of the Condition of Wounded, Sick and Shipwrecked Members of Armed Forces at Sea (opened for signature 12 Aug 1949, 75 UNTS 85 entered into force 21 October 1950); Geneva Convention (III) relative to the Treatment of Prisoners of War (opened for signature 12 Aug 1949, 75 UNTS 135, entered into force 21 Oct 1950); Geneva Convention (IV) relative to the Protection of Civilian Persons in Time of War (opened for signature 12 Aug 1949, 75 UNTS 287, entered into force 21 Oct 1950).

2. Protocol Additional to the Geneva Conventions of 12 August 1949, and Relating to the Protection of Victims of International Armed Conflicts (opened for signature 8 Jun 1977, 1125 UNTS 3; entered into force 7 Dec 1978) ('Additional Protocol I, AP I'); Protocol Additional to the Geneva Conventions of 12 August 1949, and Relating to the Protection of Victims of Non-International Armed Conflicts (opened for signature 8 Jun 1977, 1125 UNTS 609; entered into force 7 Dec 1978).

3. Article 10 of the Constitution of the Czech Republic (No. 1/1993 Coll.): Promulgated treaties, to the ratification of which the Parliament has given its consent and by which the Czech Republic is bound, form a part of the legal order; if a treaty provides something other than that which a statute provides, the treaty shall apply.

4. The Geneva Conventions and the Additional Protocols were promulgated under Nos. 65/1954 Coll. and 168/1991 Coll. respectively.

5. Article 54 of Geneva Convention I or Article 45 of Geneva Convention II.

6. Act No. 126/1992 Coll., on the Protection of the Red Cross Emblem and Name and on the Czechoslovak Red Cross, as amended.

7. Act No. 40/2009 Coll., the Penal Code, as amended.

8. Act. No. 221/1999 Coll., on Career Soldiers, as amended.

9. As law of war and IHL (or law of armed conflict) are usually used as synonyms, this wording may be considered imprecise.

10. Zákl-1 Základní řád ozbrojených sil ČR; approved by the President of the Czech Republic as the commander in chief of the Armed Forces in 2001, legally binding for all members of the Armed Forces.

11. Všeob-̌̌-1 Polní řád pozemních sil Armády České republiky; approved by the Minister of Defence in 1997, legally binding for all members of the Armed Forces.

12. STANAG 2931 was implemented by a military regulation Oper-1-9 Maskování ochranných zdravotnických znaků na zemi v taktických operacích.

13. Jean Pictet (ed.), International Committee of the Red Cross, "The Geneva Conventions of 12 August 1949: Commentary I Geneva Convention for the Amelioration of the Condition of the Wounded and Sick in Armed Forces in the Field", Martinus Nijhoff, 1952, p. 307.

14. Clapham, A., Gaeta, P., Sassòli, M. “The 1949 Geneva Conventions: A Commentary”, Oxford University Press, 2015 , p. 883 .

15. Jean Pictet (ed), International Committee of the Red Cross, "The Geneva Conventions of 12 August 1949: Commentary I Geneva Convention for the Amelioration of the Condition of the Wounded and Sick in Armed Forces in the Field", Martinus Nijhoff, 1952, p. 348.

16. STANAG 2449 was implemented by a military regulation Vševojsk-2-17 Př́íprava a výcvik v právu ozbrojeného konfliktu.

17. Article 87(2) of the Additional Protocol I

18. Regulative framework for the system of legal service in the Czech Armed Forces was given by RMO 29/2010 Právní podpora v rezortu Ministerstva obrany, approved by the Minister of Defence in 2010.

19. Advisory Service of the ICRC, fact sheet "Respecting and Protecting Health Care in Armed Conflicts and in Situations Not Covered by International Humanitarian Law". Electronic copy available at https://www.icrc.org/eng/assets/files/2012/health-care-law-factsheet-icrc-eng.pdf. 
20. As listed in Section 53 of Act. No. 221/1999 Coll., on Career Soldiers, as amended.

21. Act No. 40/2009 Coll., the Penal Code, as amended.

22. Sassòli, M. The Implementation of International Humanitarian Law : Current and Inherent Challenges. Yearbook of International Humanitarian Law 2007, p. 70. Electronic copy available at https://archiveouverte.unige.ch/unige: 864

23. Sassòli, M. "IHL mechanisms in armed conflict: Where is the problem?" in Michel Veuthey (ed) "Respecting International Humanitarian Law: Challenges and Responses", International Institute of Humanitarian Law, 2014, p. 109-115. Electronic copy available at http://www.iihl.org/wp-content/uploads/2015/12/IHL-Challengesand-Responses.pdf 